FINAL TECHNICAL REPORT

Project Title: Coupled Geochemical and Hydrological Processes Governing the Fate and Transport of Radionuclides and Toxic Metals Beneath the Hanford Tank Farms

Covering Period: Year $1-3$

Date of Report: June, 2006

Recipient: $\quad$ Stanford University

Award Number: $\quad$ DE-FG07-02ER63516

Contact(s): $\quad$ Scott Fendorf

Phone: $650-723-5238$

Email: fendorf@stanford.edu

Phil Jardine

Phone: 865-574-8058

Email: Jardinepm@ornl.gov

\title{
Project Summary:
}

The goal of this research was to provide an improved understanding and predictive capability of coupled hydrological and geochemical mechanisms that are responsible for the accelerated migration and immobilization of radionuclides and toxic metals in the vadose zone beneath the Hanford Tank Farms. The study was motivated by the technological and scientific needs associated with the long-term management of the enormous in-ground inventories of multiple contaminants at the Hanford site. Here we have quantified the rates and mechanisms of toxic metal interaction with the solid phase under various hydrologic conditions. Our approach involved (1) field-relevant, long-term unsaturated flow and transport experiments in undisturbed Hanford sediments, (2) an experimental design configuration that provides the ability to delineate complex geochemical processes, such as redox transformations and sorption, in different sediment pore regimes during reactive contaminant transport, and (3) the use of novel surface analytical techniques to quantify the distribution and chemical environment of contaminants as a function of sediment lithology and water content. We observe that distinct flow paths (preferential flow) occur even in coarse-textured sediments, and that vertical flow is partially restricted by lithologic discontinuities, resulting in perched water tables and unstable wetting fronts. The early breakthrough and significant separation of tracer in the effluent suggest that large pockets of immobile water develop creating a condition of physical nonequilibrium between flowing domains and immobile domains. 
From a contaminant transport perspective this process is advantageous since the presence of large pockets of immobile water will significantly impede the vertical migration of waste being released from the Hanford tanks. Chromium(VI) transport through the vadose zone sediments is predicated on the prevalence and reactivity of $\mathrm{Fe}(\mathrm{II})$-bearing phases along distinct flow-paths; owing to the low adsorption capacity for $\mathrm{Cr}(\mathrm{VI})$ and limited bacterial respiration (particularly anaerobic respiration), $\mathrm{Cr}(\mathrm{VI})$ attenuation is entirely dependent upon reaction with existing (geogenic) Fe(II) phases such as magnetite and biotite. Chromium(VI) reduction by Hanford sediments is negligible unless pretreated with acid or base due to surficial coatings on Fe(II) phases that limits their reactivity. Pretreatment of packed mineral beds with an acidic solution results in $\mathrm{Cr}$ (VI) influent solutions being reduced to $\mathrm{Cr}$ (III) via reaction with the minerals antigorite and lizardite in addition to magnetite and Fe(II)-bearing clay minerals. In sediments environments near the tanks, hyper alkaline conditions occur and $\mathrm{Cr}(\mathrm{VI})$ reduction proceeds via dissolution of silicate-bearing Fe(II) minerals such as biotite-with oxidation-reduction occurring via reaction of aqueous constituents near the host mineral surface. Additionally, under the alkaline conditions of the near-tank environment, $\mathrm{Cr}$ (III) and $\mathrm{Cr}(\mathrm{VI})$ form a portlandite mineral assemblage, indicating a secondary mechanism for chromium retention at high $\mathrm{pH}$. By unraveling fundamental contaminant transport mechanisms in complex porous media, we provide an improved conceptual understanding and predictive capability of a variety of vadose issues within the DOE system.

\section{Background:}

Site Hydrogeology

The Hanford Site is located in the semi-arid Pasco Basin of the Columbia Plateau in south-central Washington State. The major geologic units of the vadose zone are the Hanford Formation which overlies the Ringold Formation. The Hanford Formation consists of fine- to coarse-grained sands and gravels deposited by the cataclysmic floods of the Pleistocene; embedded caliche beds are also found in the Hanford Formation (Figure 1). The Ringold Formation consists of semi-consolidated clays, silt, pedogenically-altered sediment, fine- to coarse-grained sands and gravel. The Plio-Pleistocene Unit (sandy gravels) and early Palouse soil (eolian, loess-containing) separate the two formations. The Hanford Formation generally lies above the water table except in the eastern (300 Area) and northern (100 Area) parts of the site. Ringold strata are typically below the water table except in the central (200 Area) of the site, where they comprise $\sim 15 \%$ of the vadose zone material.

The vadose zone sediments at the site are generally coarse $(70-80 \%$ sand and gravel), oxic, low clay content $(<1-10 \%)$, and very low organic carbon $(<1 \%)$. Due to stratification the hydraulic conductivity is highly spatially variable. Nevertheless, the hydraulic conductivity for the Hanford Formation is thought to be one order of magnitude higher than for the Ringold Formation and horizontal conductivities are thought to be 100 times higher than vertical conductivities. Factors that are poorly understood in the general hydrogeologic framework include cross cutting features (clastic dikes, vertical fissures), discontinuities in strata, and the presence of unsealed or poorly sealed wells and boreholes. All these features add to the complexity of moisture flow at the site and may 
result in the rapid transport of contamination through the vadose zone to the groundwater with minimal interaction with sediments. Furthermore, perched zones of saturation (perched water tables) are known to form on top of low permeability soil lenses (clays, fine sediments), highly cemented horizons (e.g., caliche beds), and at the contact between a fine-grained stratum overlying a coarse-grained stratum. Mud sequences in the Ringold Formation and the low permeability Plio-Pleistocene unit and early Palouse soil underlying the 200 Area represent major features that control the formation of perched water tables. Perched water is known to exist underneath active release sites. These perched water tables can promote significant lateral contaminant transport, where flow could potentially intercept vertical fissures. They also lead to wetting-front instabilities that promote preferential flow and transport via finger flow and funnel flow. All of these mechanisms can result in enhanced contaminant migration.

Because of the great depth to the water table underlying much of the site $(\sim 100$ $\mathrm{m})$ and the semi-arid climatic regime (16 cm average annual precipitation), contaminant migration to groundwater was considered to be a minor concern. Nevertheless, the direct disposal to soils of approximately 450 billion gallons of waste water (via cribs and trenches) raised the local water table nearly $30 \mathrm{~m}$ and effectively invalidated transport predictions predicated on natural climatic recharge. Major groundwater mounds were created underneath the 200 Area, although reduction of waste disposal has led to declines in water table elevation. In addition, an incomplete understanding of the complex vadose zone hydrology resulted in inadequate model simulations.

\section{Sediment Geochemistry}

The Hanford Site sediments are neutral to slightly alkaline with a net negative charge on soil particles which promotes the sorption of cations but anion adsorption is not favored under these conditions. Hanford Site sediments cannot be meaningfully differentiated based on chemical characteristics, with the exception of the ion-exchange capacity, which is related to the fraction of fine-grained sediments. Underneath the 200 Area, smectite is the dominant 2:1 phyllosilicate in the clay fractions from the Hanford and Ringold Formations. Illite and its weathering products vermiculite and chlorite are common on the Hanford and Upper Ringold. Smectite concentrations decrease with depth whereas the concentrations of illite, vermiculite, and chlorite increase with depth (Amonette, PNNL, unpublished data). These 2:1 phyllosilicates confer to the soil a large

capacity for ${ }^{137} \mathrm{Cs}$ sorption. In fact, direct waste disposal to the soil was based on the assumption that the geochemical capacity for retaining contaminant solutes was more than adequate to prevent waste migration through the subsurface. This assumption has proven to be overly optimistic.

\section{Waste Disposal to Soils at the Hanford Site}

Enormous quantities of radioactive, chemical, and mixed wastes were generated at the Hanford Site during the production of defense-related nuclear materials over the past 40+ years (DOE, 1998). Solid wastes were typically disposed of via on-site burial, while liquid wastes were discharged to shallow subsurface cribs, French drains, trenches and injection wells. The most concentrated wastes were stored in large single-shell tanks in the 200 Area of the Hanford Site, although as tank capacity became strained permission was granted to dispose of high level liquid waste to the soil after solids were 
settled out. Most liquid waste discharges have ceased along with most production activities in the past decade, nevertheless, relatively mobile radionuclides and heavy metals, such as $\mathrm{Cr}(\mathrm{VI})$, have contaminated the aquifer beneath the site.

The extreme chemical conditions in some near-source locations have likely significantly altered sediment properties and affected the interaction of contaminants with the sediments. For example, ${ }^{137} \mathrm{Cs}$ sorption may be inhibited due to competition with $\mathrm{Na}+$ in the wastes (as high as $10 \mathrm{M}$ in some wastes). In addition, colloids may be generated by the interaction of very high or low $\mathrm{pH}$ waste streams with the subsurface media or from the precipitation of aluminum, silica, and iron as these same waste streams are neutralized via contact with the soil. Thus, colloid-facilitated contaminant transport may be important as well.

Although accelerated transport of contaminants within the vadose zone beneath the 200-West Area Tanks has been recognized, the mechanisms responsible for the vertical migration of the radionuclides is unclear. Does horizontal stratification enhance the lateral movement of contaminants, which in turn enhances vertical preferential flow due to perched water dynamics? Do physical heterogeneities, such as stratification and pore regime connectivity, influence the retardation and degree of geochemical nonequilibrium during contaminant transport? Recent modeling efforts of the problem have failed to yield answers to this question since they are inadequately parameterized due to the lack of sufficient quality data (Piepho, 1994; Wood et al., 1996; Ward et al., 1997). The modeling effort by Ward et al. (1997) concerning radionuclide migration beneath the Hanford tanks revealed some of the first numerical evidence to suggest that funnel flow, resulting from lithological discontinuities, could be responsible for accelerated contaminant transport beneath the tanks. Fundamental experimental research is needed that will improve the conceptual understanding and predictive capability of radionuclide migration in the Hanford tank-farm environment. Since geochemical reactions are directly linked to the system hydrodynamics, coupled geochemical and hydrological processes must be investigated in order to resolve the key mechanisms contributing to vadose zone and groundwater contamination at Hanford.

\section{Project Objectives:}

This project addresses the goals of the Environmental Management Sciences Program (EMSP) that seeks innovative basic research to benefit cleanup technologies and decision-making strategies for contaminated environments. Our project specifically addresses Hanford research needs in subsurface science by contributing to the objectives of the Tank Farm Vadose Characterization Project and the 200 Area Remedial Action Project, which are components of the Hanford Site Groundwater/Vadose Zone Integration Project (Integration Project). The work advances the technological and scientific needs associated with the long-term management of the enormous in-ground inventories of ${ }^{235 / 238} \mathrm{U},{ }^{99} \mathrm{Tc},{ }^{60} \mathrm{Co}$, and $\mathrm{Cr}(\mathrm{VI})$ present at the Hanford site. We believe that scientifically defensible predictions of contaminant transport and strategies for remediation must be based upon a field-relevant understanding of coupled hydrological and geochemical processes that control subsurface contaminant fate and transport. This 
research project investigates the migration of $\mathrm{Cr}(\mathrm{VI})$ in undisturbed sediments from the Hanford site using realistic experimental protocols designed to delineate complex hydrological and geochemical processes controlling contaminant movement. The specific research objectives of this project were to:

- $\quad$ Provide an improved understanding of how preferential vertical and lateral flow, and the formation of immobile water influence the transport of radionuclides and toxic metals in heterogeneous, laminated sediments.

- Quantify the rates and mechanisms of radionuclide and toxic metal interaction with the solid phase under various hydrologic conditions.

- $\quad$ Provide new insights into how physical and mineralogical heterogeneities (e.g. stratification, pore regime connectivity, mineral composition along flowpaths) influence contaminant retardation and the degree of geochemical nonequilibrium during transport.

The overall research products will be (1) knowledge and information in previously unexplored areas of vadose zone fate and transport to support EM's performance/risk assessment and decision-making process for Tank Farm restoration; and (2) improved predictive strategies for assessing the transport rate and fate of redox active contaminants, such as $\mathrm{Cr}(\mathrm{VI})$, beneath the Hanford Tank Farms. Since this project unravels fundamental contaminant transport mechanisms in complex porous media, the results should assist in improving our overall conceptual understanding and predictive capability of a variety of vadose zone issues within the DOE system.

\section{Project Results and Implications:}

Hydrologic Processes

A series of important hydrologic breakthroughs were made in this study. First, we discerned that saturated and unsaturated hydraulic conductivity of cores acquired parallel to lithological layering was an order of magnitude more rapid than the conductivity of cores acquired perpendicular to lithological layering. Thus, lateral flow beneath the tank farms is a strong contributor to the spread of contaminants. Also, the conductivity of fine-grained cores were an order of magnitude slower than core acquired in sandy media.

The transport of the three nonreactive tracers at different degrees of unsaturation showed essentially no difference in breakthrough patterns when flow remained unrestricted along continuous lithological features as is the case for the horizontal cores (Figure 1). This suggested that physical nonequilibrium conditions were not occurring during lateral flow in these sediments. Thus matrix diffusion processes are not contributing to the attenuation of waste being released from the Hanford tanks allowing for more rapid transport rates beneath the tank farms. 
When flow is partially restricted by lithologic discontinuities as is the case for the vertical cores (e.g. alternating coarse and fine layers), perched water tables develop resulting in unstable wetting fronts and the prevalence of preferential flow. The early breakthrough and significant separation of tracer in the effluent suggest that large pockets of immobile water develop creating a condition of physical nonequilibrium between flowing domains and immobile domains. From a contaminant transport perspective this process is advantageous since the presence of large pockets of immobile water will significantly impede the vertical migration of waste being released from the Hanford tanks.



Figure 1. Multiple tracer transport through intact Ringold sediments under saturated and unsaturated conditions.

\section{Adsorption Processes}

Significant findings regarding geochemical processes in sediments beneath the tanks.

Reactive transport of $\mathrm{Sr}$ and $\mathrm{U}$ in undisturbed Hanford cores and $\mathrm{U}$ in undisturbed consolidated material of the Plio-Pleistocene unit were conducted. The Plio-Pleistocene unit was not conducive to either preferential vertical finger flow or to lateral flow, as no tracer separation (Br/PFBA/PIPES) was observed under our experimental conditions (Figure 1). The absence of distinct sedimentary bedding in the Plio-Pleistocene probably accounts for this observation. Our results therefore suggest that physical nonequilibrium processes will be minimal in the Plio-Pleistocene unit. Reactive transport of ${ }^{235 / 238} \mathrm{U}$ through the Plio-Pleistocene unit exhibited evidence of nonequilibrium, possibly influenced by kinetics or multi-site/multi-species reactivity. Sorption of ${ }^{235 / 238} \mathrm{U}$ was significantly enhanced under equilibrium conditions when compared to transport or flowing conditions, which suggests kinetic effects on sorption. Transport experiments 
were conducted in an atmosphere representative of subsurface conditions $\left(1 \% \mathrm{CO}_{2}\right)$, which resulted in the formation of a stable uranyl-carbonate complex. Therefore, it is also likely that the large complex may have different affinities for subsurface sorption sites. Transport through the Plio-Pleistocene unit has demonstrated the presence of geochemical nonequilibrium while physical nonequilibrium processes were minimal, thus resulting in a greater understanding of the relevant mechanisms governing contaminant interactions in the Hanford subsurface. The transport of $U$ in the Hanford core shows strong and moderate reactivity (Figure 2).

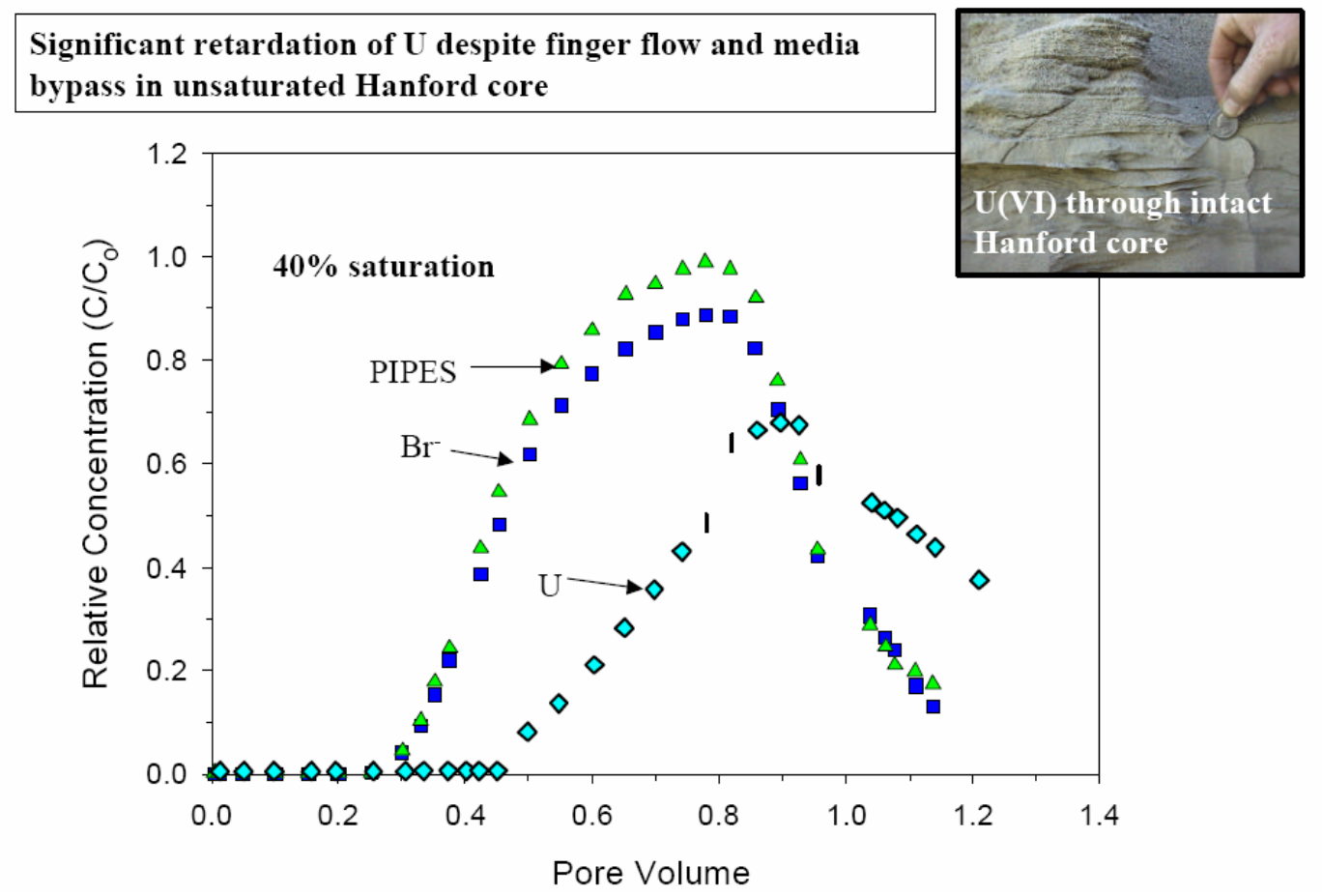

Figure 2. Transport of $\mathrm{U}(\mathrm{VI})$, and non-reactive tracers, through intact cores of Hanford sediment.

\section{Reductive Attenuation of $\mathrm{Cr}(\mathrm{VI})$}

Subsurface chromate contamination is a major environmental threat at the U.S. Department of Energy's Hanford Site. The climate of the Hanford Site is arid, with an average rainfall of $15.9 \mathrm{~cm} \mathrm{y}^{-1}$. In the 100 Area of the Hanford Site, chromate used as a corrosion inhibitor in nuclear reactor cooling water was discharged to unlined surface cribs, resulting in chromate contamination reaching the Columbia River (Poston et al., 2001), which is not only a primary source of drinking water, but also a spawning ground for salmon. Additionally, thousands of liters of hot $\left(100 \mathrm{C}^{0}\right)$, caustic $(\mathrm{pH}>14)$, chromatecontaining high-level nuclear waste (HLW), from the Reduction-Oxidation (REDOX) plutonium recovery process, has leaked into the vadose zone as a result of multiple failures of single-shell tanks in the S-SX tank farm (Jones et al., 2000). Should chromate from these tanks reach the water table, rapid migration to the Columbia River would result. Analysis of chromium's redox state in a core obtained from a HLW plume beneath tank SX 108 revealed that $29-75 \%$ of the total $\mathrm{Cr}$ had been reduced to immobile $\mathrm{Cr}$ (III) (Zachara et al., 2004). 
In aerobic, arid environments, with limited organic carbon, chromate reductants are essentially restricted to Fe(II)-bearing mineral phases of geologic origin. Potential sources of $\mathrm{Fe}$ (II) in the Hanford sediments include iron-bearing silicates such as lizardite $\left[\mathrm{Mg}_{\mathrm{x}} \mathrm{Fe}_{3-\mathrm{x}} \mathrm{Si}_{2} \mathrm{O}_{5}(\mathrm{OH})_{4}\right]$, antigorite $\left[(\mathrm{Mg}, \mathrm{Fe})_{3} \mathrm{Si}_{2} \mathrm{O}_{5}(\mathrm{OH})_{4}\right]$, biotite, magnetite, and ilmenite. Chromate reduction by $\mathrm{Fe}(\mathrm{II})$-bearing minerals is controlled by their surface reactivity. Mineral surface coatings such as carbonates, silicates, and Fe(III) (hydr)oxides, however, may inhibit electron transfer from underlying $\mathrm{Fe}(\mathrm{II})$ to aqueous $\mathrm{Cr}(\mathrm{VI})$ (Doyle et al., 2004; Kendelewicz et al., 2000; Peterson et al., 1997), all of which commonly form in the vadose-zone of arid environments.

In the Hanford subsurface, chromium contamination has occurred in two distinct geochemical environments, 'near-tank' and 'far-field'. The near-tank environment is characterized by high $\mathrm{pH}$, salt concentration, and temperature, resulting in extensive mineral dissolution and surface modification. The far-field environment is representative of the background geochemical conditions (circumneutral $\mathrm{pH}$, ambient temperature, etc.). These conditions would be relevant at locations far from a leaking tank, or in arid environments with limited co-contamination. We examined the reduction of chromate by sediment obtained from the Hanford formation beneath the Interim Disposal Facility (IDF) at the Hanford Site. In addition to providing information about chromate reduction specific to the Hanford Site, these experiments provide generally applicable information about abiotic chromate reduction pathways in natural media, particularly relevant to soils and sediments of arid environments.

Impact of Alkaline Conditions on Cr(VI) Retention: To simulate mineral reactivity under near-field geochemical conditions beneath a leaking tank, a feed solution of $10 \mathrm{M}$ $\mathrm{NaOH}$, containing $0.2 \mathrm{mM} \mathrm{K}_{2} \mathrm{CrO}_{4}$, was utilized. Chromate removal is observed in the first pore-volume of effluent. After 40 pore volumes the effluent chromate concentration was $0.16 \mathrm{mM}$ (Figure 3), and the effluent chromate concentration remained below the

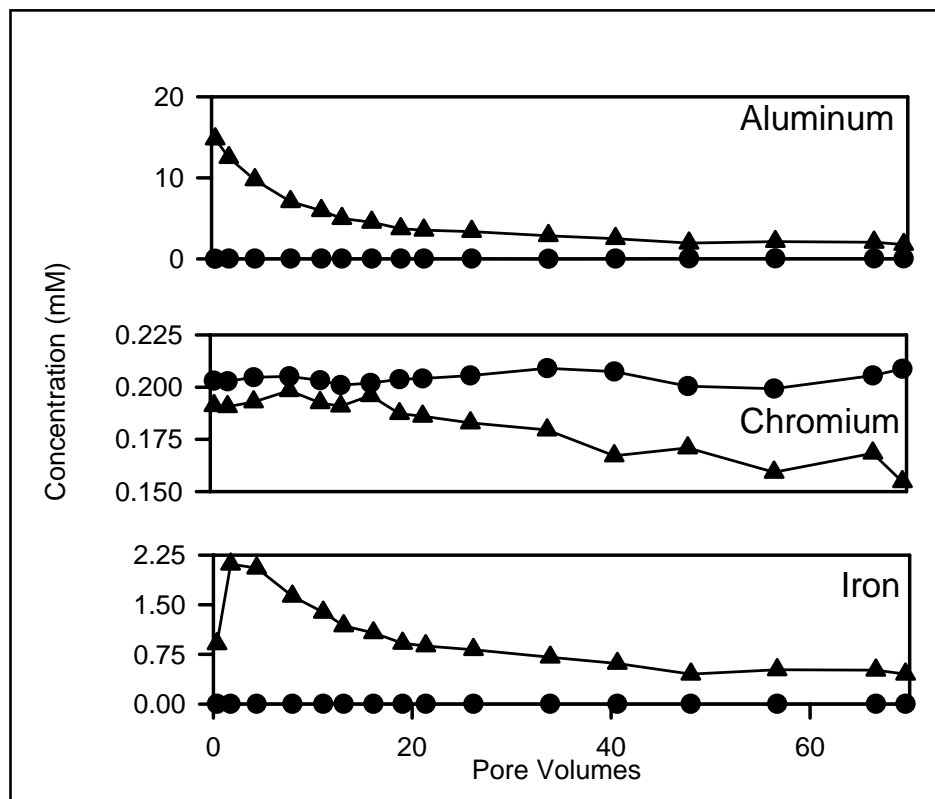

Figure 3. Effluent metal concentration for control $(\bullet)$ and $10 \mathrm{M}$ $\mathrm{NaOH}$ columns $(\boldsymbol{\Delta})$. influent concentration $(0.2$ $\mathrm{mM}$ ) until the termination of the experiment.

The $\mathrm{Cr}(\mathrm{VI})$ pre-edge feature in XANES spectra reveals $\mathrm{Cr}(\mathrm{VI})$ in all identified $\mathrm{Cr}$ hot spots (Figure 4)-which is confirmed by the presence of Cr-O shells at $1.6 \AA$ in the EXAFS spectra (Figure 4). The points of high $\mathrm{Cr}$ concentration in the $10 \mathrm{M}$ $\mathrm{NaOH}$ column contain 13 to $26 \% \mathrm{Cr}(\mathrm{VI})$ (Figure 4) exibit a $\mathrm{Cr}-\mathrm{Cr}(\mathrm{Fe})$ structure similar to $\alpha / \beta-\mathrm{MeOOH}(\mathrm{Me}=\mathrm{Fe}$ or $\mathrm{Cr}$ ) (Figure 4), with scattering contributions from 
$\mathrm{Al}(\mathrm{Si})$ at $\sim 3.1 \AA$, consistent with aluminum substitution, and $\mathrm{Cr}(\mathrm{Fe})$ at $\sim 3.5 \AA$. Comparatively, goethite $(\alpha-\mathrm{FeOOH})$ has $\mathrm{Fe}-\mathrm{Fe}$ shells at 3.01, 3.29 and $3.43 \AA$ (34) and akaganeite $(\beta-\mathrm{FeOOH})$ at $3.03,3.34,3.50$, and $3.55 \AA$ (35). Lizardite and portlandite $(\mathrm{CaOH})$ were commonly associated with high chromium concentrations (Figure 5), and magnetite was detected in one sample (Figure 6). A chromium-rich grain of portlandite was also isolated (Figures 5 and 6 ), in which $20 \%$ of the chromium resides as $\mathrm{Cr}(\mathrm{VI})$ (data not shown).
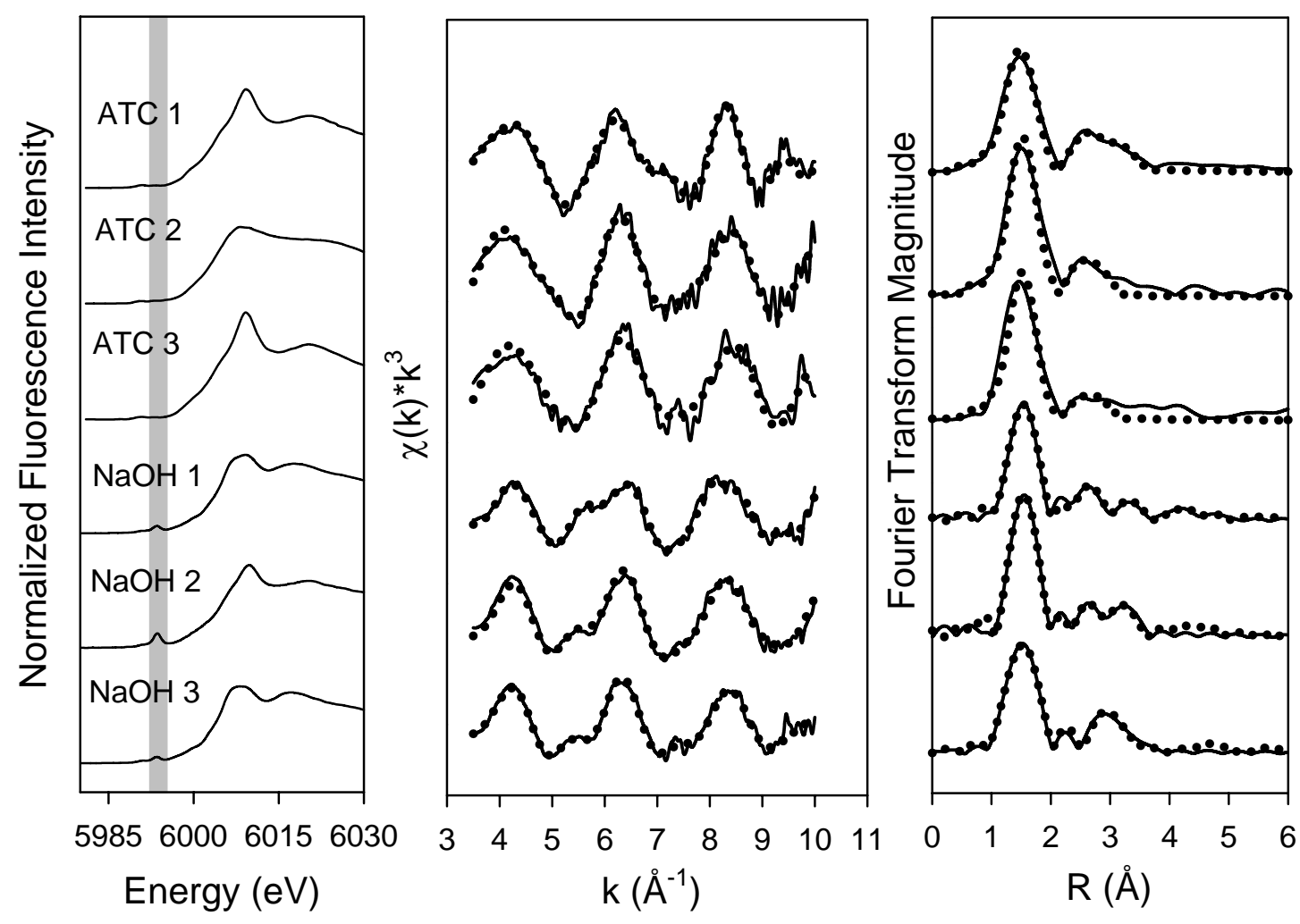

Figure 4. Chromium K-edge XANES (left), EXAFS (center), and Fourier-transformed EXAFS (right) spectra from three areas of high $\mathrm{Cr}$ concentration in sediments from acid pre-treated (ATC $1-3$ ) and $10 \mathrm{M}$ $\mathrm{NaOH}(\mathrm{NaOH} 1$ - 3) column experiments. EXAFS data (center; solid lines) were fit (center, dotted lines) over $k=3.5-10 \AA^{-1}$. Fourier transforms of data (right, solid lines) and fits (right, dotted lines) were calculated over the same $k$ range.

Dissolution of Fe(II)-bearing minerals (antigorite, biotite, lizardite, and magnetite) induced by the extreme alkalinity leads to the dispersal of $\mathrm{Fe}(\mathrm{II})$ and consequential chromate reduction/retention throughout the mineral matrix as exemplified by a detailed examination of a hand-picked mica grain (Figure 6). XANES spectra obtained from several points show $\mathrm{Cr}(\mathrm{III})$, and line scans across the particle indicate that $\mathrm{Cr}$ is distributed throughout the mineral surface (Figure 6). Despite the preponderance of $\mathrm{Cr}(\mathrm{III}), \mathrm{Cr}(\mathrm{VI})$ was noted within the sample, in part through sequestration within portlandite (Figures 5 and 6 ). As a result of the multiple retention mechanisms, $1.1 \mathrm{mmol}$ 
$\mathrm{Cr} \mathrm{Kg}^{-1}$ sediment is retained in the column reacted with a feed solution containing $10 \mathrm{M}$ $\mathrm{NaOH}$.
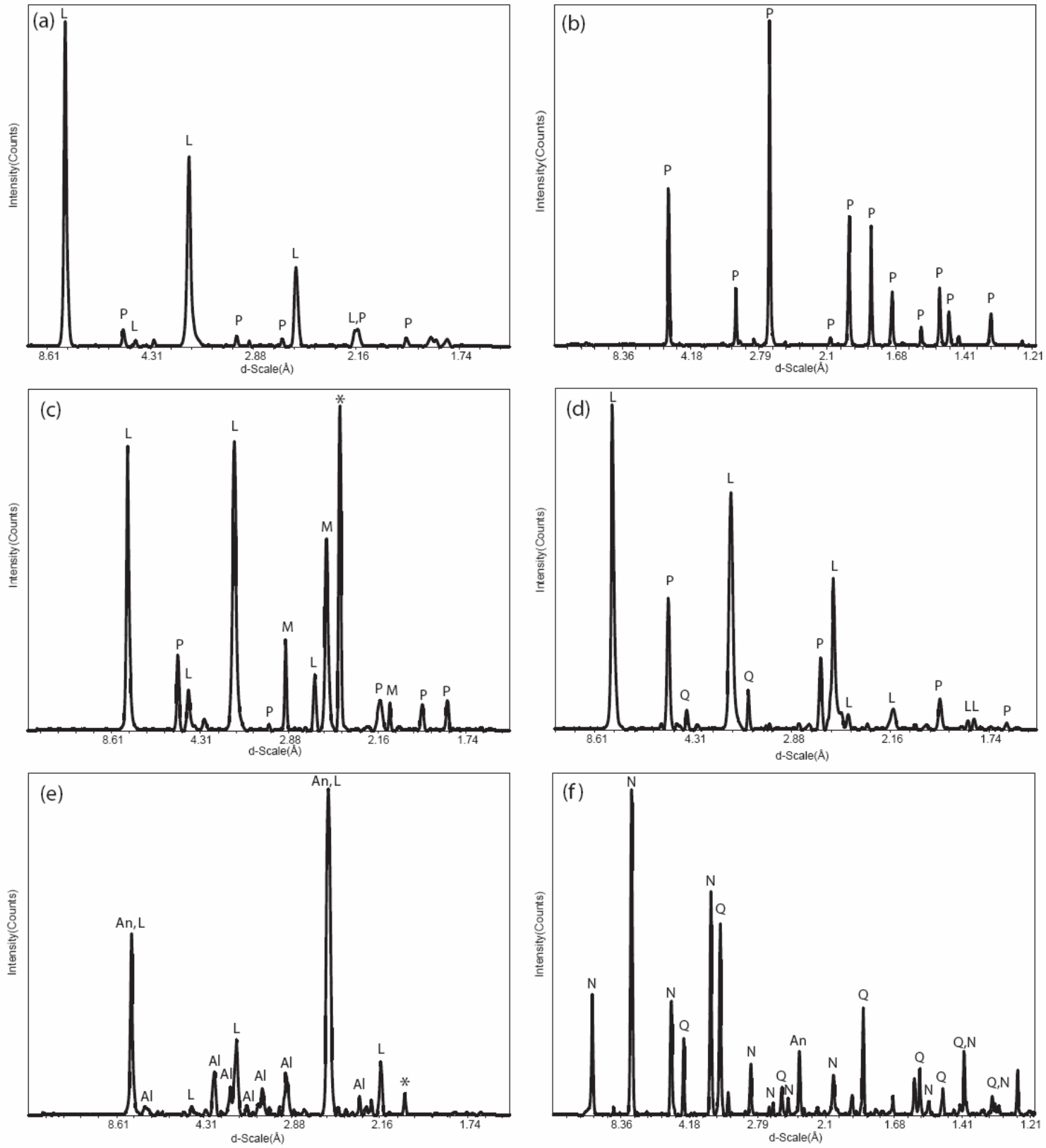

Figure 5. XRD patterns obtained from areas of high chromium concentration in sediments from $10 \mathrm{M}$ $\mathrm{NaOH}$ (a-d) and acid pre-treated (e-f) columns. Minerals identified in the patterns include portlandite (P), lizardite $(\mathrm{L})$, magnetite $(\mathrm{M})$, quartz $(\mathrm{Q})$, nimite $(\mathrm{N})$, antigorite $(\mathrm{An})$, and albite $(\mathrm{Al})$. Unidentifiable single scattering peaks are indicated with an "*”. 


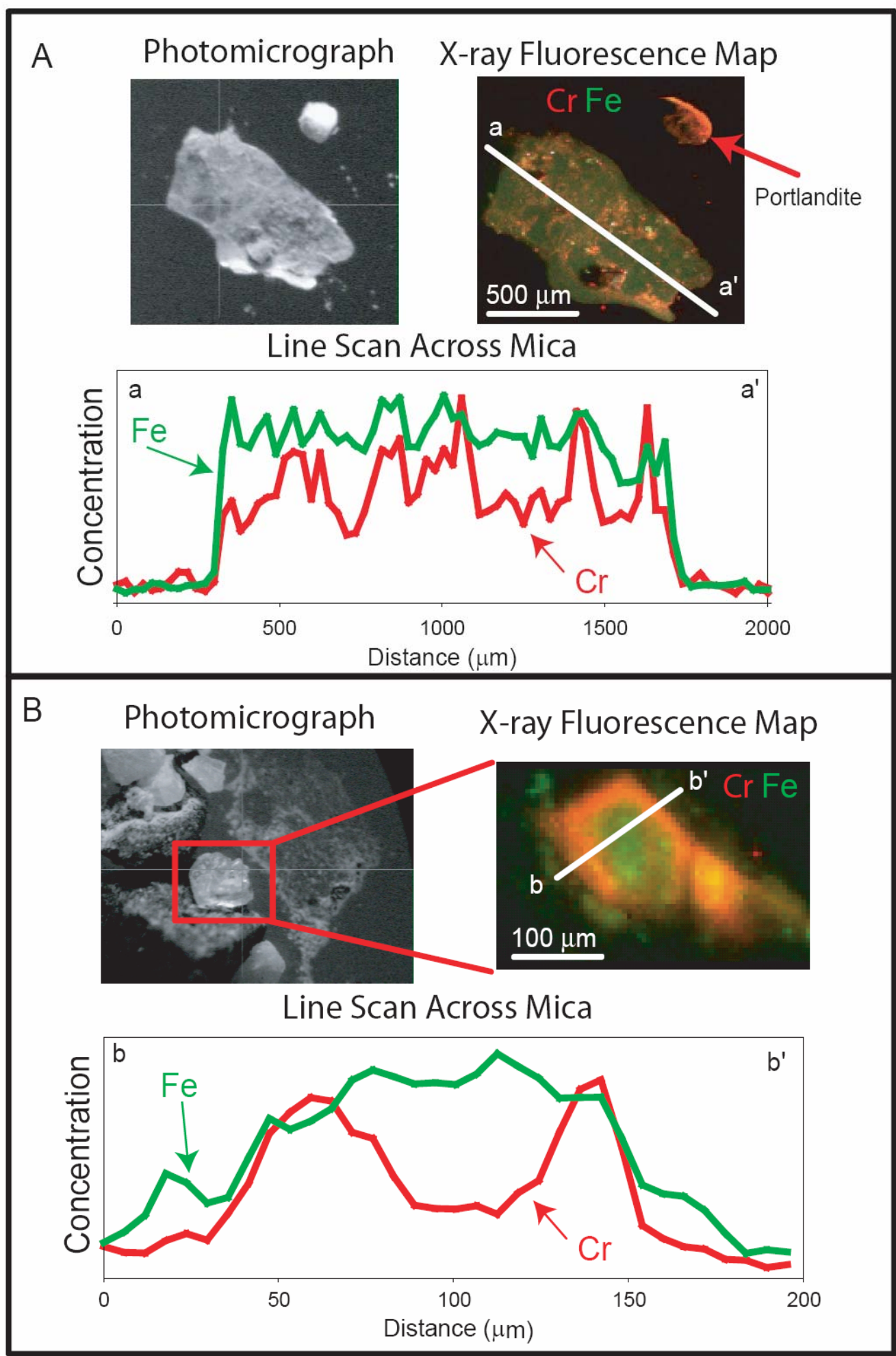

Figure 6. Microanalysis of mica grains from $10 \mathrm{M} \mathrm{NaOH}$ (A) and acid pre-treated (B) columns. In XRF maps, $\mathrm{Cr}$ distribution is shown in red and $\mathrm{Fe}$ in green. 
Chromate Reduction in Far-Field Environments: Chromate reduction by non-treated IDF 5 sediment was investigated under far-field conditions (those representative of the 'native' geochemistry) using a feed solution of $0.2 \mathrm{mM} \mathrm{K}{ }_{2} \mathrm{CrO}_{4}$ in $0.2 \mathrm{mM} \mathrm{CaCl} 2$ adjusted to $\mathrm{pH}$ 8. Chromate breakthrough is commensurate with $\mathrm{Br}^{-}$indicating limited to no retardation (Figure 7). Several pre-treatments were then used to target different types of surface coatings that may inhibit electron transfer from underlying $\mathrm{Fe}(\mathrm{II})$ to $\mathrm{Cr}(\mathrm{VI})$.

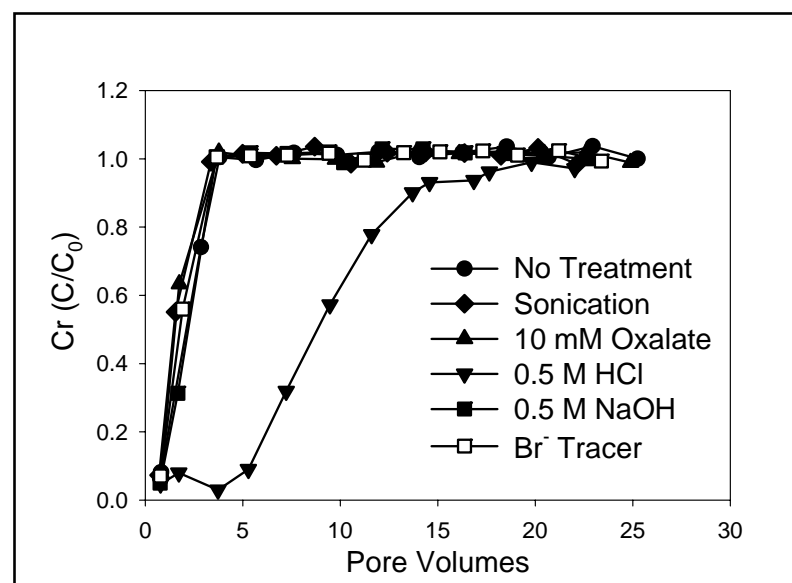

Figure 7. Effect of sediment pre-treatment on $\mathrm{Cr}(\mathrm{VI})$ breakthrough. The sediment was pre-treated with 10 pore volumes of the indicated treatment, followed by equilibration with 10 pore-volumes 0.2 $\mathrm{mM} \mathrm{CaCl} 2$ at $\mathrm{pH} 8$, prior to the introduction of the $0.2 \mathrm{mM} \mathrm{K}_{2} \mathrm{CrO}_{4}$ solution.
Sonication was used to simulate physical abrasion, $0.5 \mathrm{M} \mathrm{NaOH}$ to promote dissolution of silicate phases, $10 \mathrm{mM}$ oxalate to provide a complexant to dissolve $\mathrm{Fe}(\mathrm{III})$ and other metal (hydr)oxide phases, and $0.5 \mathrm{M} \mathrm{HCl}$ to induce acidic dissolution of metal oxide and carbonate phases. Ferrous iron was noted only in the acid treatment, with 0.16 mmoles $\mathrm{Fe}$ (II) $\mathrm{g}^{-1}$ removed, and was the only system to retard $\mathrm{Cr}(\mathrm{VI})$ breakthrough (Figure 7)—solid phase $\mathrm{Cr}$ was exclusively in the trivalent state (Figure 5). As a consequence of $\mathrm{Cr}$ reduction in the $0.5 \mathrm{M} \mathrm{HCl}$-treated column, nearly two orders of magnitude more chromium are deposited than unaltered solids. The effluent $\mathrm{pH}$ of the $0.5 \mathrm{M} \mathrm{HCl}$ treated column was initially

6.5 and gradually increased to 7.5 over the duration of the experiment. The effluent $\mathrm{pH}$ of the other four columns was $7.7 \pm 0.2$ for the duration of the experiment.

Chromate retention within acid pretreated sediments was further examined at three influent chromate concentrations $(0.2,0.1$, and $0.02 \mathrm{mM})$. Chromate breakthrough occurs after the elution of 20 pore volumes of $0.2 \mathrm{mM} \mathrm{Cr}(\mathrm{VI}), 40$ pore volumes of 0.1 $\mathrm{mM} \mathrm{Cr}(\mathrm{VI})$, or 100 pore volumes of $0.02 \mathrm{mM} \mathrm{Cr}(\mathrm{VI})$. A comparison of the breakthrough trends on a mass-introduced to mass-retained basis reveals two distinct regions of $\mathrm{Cr}$ uptake by the sediment. An initial region occurs after introducing between 0 to 0.007 mmoles $\mathrm{Cr}(\mathrm{VI})$ and a second region after 0.007 mmoles $\operatorname{Cr}(\mathrm{VI})$. At the highest concentration $(0.2 \mathrm{mM})$, retention is finite while at 0.1 and $0.02 \mathrm{mM} \mathrm{Cr}(\mathrm{VI})$ continued $\mathrm{Cr}(\mathrm{VI})$ attenuation (tailing) results.

At all three influent concentrations, chromate reduction occurs concurrently with the presence of aqueous $\mathrm{Fe}(\mathrm{II})$. Once the aqueous Fe(II) concentration decreases below $0.005 \mathrm{mM}$, chromate reduction ceases. Aqueous Fe(II) concentrations are below 0.002 $\mathrm{mM}$ prior to the introduction of the chromate-containing feed solution $\left(\mathrm{CaCl}_{2}\right.$ wash; data not shown).

Reactive Solid Phases After Acid Treatment: High concentrations of reduced chromium associated with mafic minerals, including lizardite, antigorite (Figure 5), and nimite, a ferrous iron-bearing phyllite (Figure 5), were noted by $\mu$-XRD. Chromium(III) was observed along the edges of mica grains (Figure 6). Two iron $\mu$-EXAFS spectra 
obtained from areas on XRF maps of high $\mathrm{Cr}$ concentrations are well fit by linear combinations of ferrihydrite-nontronite and ferrihydrite-biotite.

EXAFS spectroscopy was used to probe the local structure of the mixed $\mathrm{Cr} / \mathrm{Fe}$ (hydr)oxides precipitated at points of high $\mathrm{Cr}$ concentration in solid samples from the acid-treated column. Similar to the alkaline system, shell-by-shell fitting reveals mixed $\mathrm{Cr} / \mathrm{Fe}$ precipitates in three spots of high-Cr concentration in the sediment from the acidtreated column (ATC) indicative of an $\alpha / \beta-\mathrm{MeOOH}-$ like structure (Figure 4 ).

Mechanisms and Levels of $\mathbf{C r}(\mathrm{VI})$ Reductive Attenuation: During weathering in arid, oxic subsurface environments, Fe(II)-bearing mineral reactivity, with respect to chromate, becomes compromised by a variety of weathering rinds and surface coatings. Zachara et al. (2002), for example, observed ferric (hydr)oxide rinds on biotite grains obtained from the Hanford formation sediments. In fact, using XPS analysis we observed a ferric iron layer overlying magnetite separated from IDF 5 sediments. The presence of such an oxidized layer diminishes the rate of chromate reduction due to limited transfer of electrons [or $\mathrm{Fe}(\mathrm{II})$ ] from the underlying unoxidized mineral to the aqueous interface. Owing to the passivating layer on Fe(II)-bearing minerals, physical abrasion from fast shaking speeds is required for chromate reduction within batch reactions and acid or strong base treatment is needed for reduction within column experiments performed here.

Under near-field tank conditions $(10 \mathrm{M} \mathrm{NaOH})$, the extreme $\mathrm{pH}$ induces base catalyzed dissolution of both surface coatings (e.g., Fe-hydroxides) and Fe(II)-bearing silicate minerals themselves. Under these conditions, columns having a $10 \mathrm{M} \mathrm{NaOH}$ feed solution retain more chromium than either acid pre-treated or control columns, and continue sequestering $\mathrm{Cr}$ at experiment termination (Figure 3) due to surface activation and extensive mineral dissolution. In this hyperalkaline system, XRF maps, combined with localized XRD analysis, revealed the association of high local chromium concentrations with several Fe(II)-bearing minerals, including antigorite, lizardite, and magnetite (Figure 5). EXAFS analysis of localized $\mathrm{Cr}(\mathrm{III})$ phases indicates that they have the short-range order consistent with an $\alpha / \beta \mathrm{MeOOH}$ structure, suggesting that homogeneous $\mathrm{Cr}(\mathrm{VI})$ reduction by $\mathrm{Fe}(\mathrm{II})(\mathrm{aq})$ is occurring in addition to heterogenous $\mathrm{Cr}(\mathrm{VI})$ reduction observed on mica grains.

The presence of portlandite is also detected in every instance of $\mathrm{Cr}$ deposition. Analysis of an isolated portlandite grain reveals $\mathrm{Cr}$ in association with the grain, $20 \%$ of which is in the hexavalent oxidation state. The presence of solid-phase $\mathrm{Cr}(\mathrm{VI})$ suggests that in addition to chromate reduction and subsequent precipitation, other retention mechanisms are partially responsible for the large amount of chromium retained under simulated near-field (i.e., hyperalkaline) conditions. Reduction of $\mathrm{Cr}$ (VI) to $\mathrm{Cr}$ (III) is likely inducing rapid nucleation and precipitation of portlandite, thereby trapping $\mathrm{Cr}(\mathrm{VI})$ in the solid phase. The retention of $\mathrm{Cr}(\mathrm{VI})$ at the Hanford Site has also been observed in sediment from a contaminated core obtained beneath tank SX-108, which contained $\mathrm{Cr}(\mathrm{VI})$ in addition to discrete $\mathrm{Cr}$ (III) mineral phases (Zachara et al., 2004).

The impact oxidized surface coatings on $\mathrm{Cr}(\mathrm{VI})$ reduction by $\mathrm{Fe}(\mathrm{II})$-bearing minerals is by the sediment pre-treatment experiments, where chromate reduction is only observed after the acidic dissolution of Fe(III) (hydr)oxide surface coatings. Similar to the alkaline column, localized high-chromium concentrations are associated with Fe(II)- 
bearing minerals including biotite, antigorite, lizardite, nimite (a ferrous-bearing phyllosilicate); however, less chromium is retained by the sediment. The relationship of dissolved $\mathrm{Fe}$ and $\mathrm{Cr}$ in column-effluent suggests that initial $\mathrm{Cr}(\mathrm{VI})$ reduction is being mediated by soluble Fe(II). Chromium(VI) concentrations are anticorrelated with $\mathrm{Fe}(\mathrm{II})$ concentrations, and $\mathrm{Cr}(\mathrm{VI})$ is not detected in the effluent until Fe(II) decreases below $0.005 \mathrm{mM}$. Acidic pre-treatment results in the activation of a limited number of Fe(II) surface sites, and as chromate reduction proceeds, it becomes self-inhibited by the oxidation of the underlying mineral phase and precipitation of mixed $\mathrm{Cr}(\mathrm{III}) / \mathrm{Fe}(\mathrm{III})$ (hydr)oxide phases (Figure 4). A feed solution containing $0.2 \mathrm{mM} \mathrm{Cr}$ (VI) results in more rapid surface passivation than the lower influent chromate concentrations of 0.1 and 0.02 $\mathrm{mM}$. However, due to competition of $\mathrm{Cr}(\mathrm{VI})$ for $\mathrm{Fe}(\mathrm{II})$ with molecular oxygen in aerated systems, less chromate is reduced in the $0.02 \mathrm{mM}$ column than the $0.1 \mathrm{mM}$ column owing, in part, to a 5-fold longer reaction period to achieve comparable $\mathrm{Cr}$ quantities .

Attenuation of chromate in arid environments will be governed by the reactivity of Fe(II)-bearing mineral phases, which is controlled by mineral solubility and surface reactivity. Chromate reduction by sediments of the Hanford formation under native geochemical conditions $(\mathrm{pH}<8)$ is inhibited by surface coatings and low mineral solubility. Acidic dissolution of Fe(III) (hydr)oxide layers restores the redox activity of $\mathrm{Fe}(\mathrm{II})$ minerals, resulting in chromate reduction; however, generation of $\mathrm{Cr}$ (III) and $\mathrm{Fe}(\mathrm{III})$ (hydr)oxide surface layers during $\mathrm{Cr}(\mathrm{VI})$ reduction further comprises redox activity. Conversely, near-field conditions $(\mathrm{pH}>14)$ cause extensive base-induced mineral dissolution and $\mathrm{Fe}(\mathrm{II})$ release, resulting in chromate retention throughout the mineral matrix.

Serpentine subgroup minerals (i.e., lizardite and antigorite) are quite common and widely distributed in mafic rocks. Up to $60 \%$ of the total iron in lizardite occurs in the reduced state; likewise, $90 \%$ of the total iron in antigorite occurs in the reduced state. This accounts for $3 \%$ and $40 \%$ of the octahedrally-coordinated cations in lizardite and antigorite, respectively. Therefore, notwithstanding the contributions of magnetite, they combine with biotite to comprise an important reservoir of $\mathrm{Fe}$ (II) for chromate reduction. Under conditions that induce silicate mineral dissolution, such as the near-field geochemical environment at the Hanford Site, chromate reduction will thus be enhanced by release of $\mathrm{Fe}(\mathrm{II})$. Thus, to thoroughly evaluate chromate reduction in arid environments, viable reductants under the relevant geochemical conditions must be considered. Given the paucity of organic matter within such systems, primary Fe(II)bearing mineral phases will likely be the dominant reductant. The surface reactivity and solubility of such minerals thus need to be appreciated in deciphering the rate and extent of chromate reduction.

\section{Literature Cited}

DOE. 1998. Appendix G, GW/VZ Integration Project Specification, DOE/RL-98-48, Draft C, U.S. Department of Energy, Richland, WA. 
Piepho, M.G. 1994. Bounding flow and transport analysis of 105A mock-up tank tracer test. WHC-SD-TI-646, Westinghouse Hanford Company, Richland, Washington.

Wood, M.I., R.K. Khaleel, P.D. Rittman, A.H. Lu, S.H. Finfronk, R.J. Serne, and K.J. Cantrell. 1996. Performance assessment for the disposal of low-level waste in the 200 west area burial grounds. WHC-EP-0645.

Ward, A.L., G.W. Gee, and M.D. White. 1997. A comprehensive analysis of contaminant transport in the vadose zone beneath tank SX-109. Pacific Northwest National Laboratory, PNNL-11463, UC-702.

Poston, T. M.; Hanf, R. W.; Dirkes, R. L.; Morasch, L. F. "Hanford site environmental report for calendar year 2000," Pacific Northwest National Laboratory, 2001.

Jones, T. E.; Watrous, R. A.; G.T., M. "Inventory estimates for single-shell tank leaks in S and SX tank farms," CH2M Hill Hanford Group, Inc., 2000.

Zachara, J. M.; Ainsworth, C. C.; Brown, G. E.; Catalano, J. G.; McKinley, J., P.; Qafoku, O.; Smith, S. C.; Szecsody, J. E.; Traina, S. J.; Warner, J. A. Chromium speciation and mobility in a high level nuclear waste vadose zone plume. Geochim. Cosmochim. 2004, 68, 13-30.

Peterson, M. L.; White, A. F.; Brown, G. E.; Parks, G. A. Surface passivation of magnetite by reaction with aqueous Cr(VI): XAFS and TEM results. Environ. Sci. Technol. 1997, 31, 1573-1576.

Kendelewicz, T.; Liu, P.; Doyle, C. S.; Brown, G. E. Spectroscopic study of the reaction of aqueous Cr(VI) with Fe3O4(111) surfaces. Surface Science 2000, 469, 144-163.

Doyle, C. S.; Kendelewicz, T.; Brown, G. E. Inhibition of the reduction of Cr(VI) at the magnetite-water interface by calcium carbonate coatings. Applied Surface Science 2004, 230, 260-271.

Zachara, J. M.; Smith, S. C.; McKinley, J., P.; Serne, J. N.; Gassman, P. L. Sorption of $\mathrm{Cs}+$ to micaceous subsurface sediments from the Hanford site. Geochim. Cosmochim. Acta. 2002, 66, 193-211.

\section{Publications:}

Ginder - Vogel, M., T. Borch, M. Mayes, P. Jardine, and S. Fendorf. 2005. Chromate reduction and retention processes within Hanford sediments. Environ. Sci. Technol. 39: 7833-7839.

Ginder-Vogel, M; Borch, T; Fendorf, S. 2005. Reduction and retention processes within arid subsurface environments. Geochim. Cosmochim. Acta 69: A619.

Gwo, J. P. ; Mayes, M. A. ; Jardine, P.M. 2002. Reactive transport in fractured saprolite: Determining diffusive mass transfer and surface reaction kinetics parameters.

Geochim. Cosmochim. Acta 66: A300. 
Mayes, MA ; Jardine, PM ; Mehlhorn, TL ; Bjornstad, BN ; Ladd, T ; Zachara, JM. 2003. Transport of multiple tracers in variably saturated humid region structured soils and semi-arid region laminated sediments. J. Hydrology 275: 141-161.

Pace, M. N.; Mayes, M .A. ; Jardine, P. M. ; Mehlhorn, T. L.; Zachara, J.M.; Bjornstad, B.N. 2005. Quantifying the effects of small-scale heterogeneities on flow and transport in undisturbed core from the Hanford formation. Vadose Zone J. 4: 12201223. 